PRINT ISSN 1119-8362

Electronic ISSN 1119-8362
Full-text Available Online at https://www.ajol.info/index.php/jasem http://ww.bioline.org.br/ja
J. Appl. Sci. Environ. Manage. Vol. 25 (6) 969-975 June 2021

\title{
Assessment on the Effects of Potting Media on Seed Germination and Early Seedling Growth of Pterocarpus erinaceus Poir
}

\author{
${ }^{*}$ PETER, MK; ${ }^{2}$ AGERA, SIN; ${ }^{2}$ AMONUM, JI \\ ${ }^{I}$ Department of Forestry Technology, Federal College of Forestry, Jos. Nigeria \\ ${ }^{2}$ Department of Forest Production and Products, College of Forestry and Fisheries, University of Agriculture, Makurdi, P.M.B. 2373 \\ Makurdi, Benue State, Nigeria \\ *Corresponding Author Email: micahpeter35@gmail.com, Tel: +234 7030653780 \\ Co-authors Email: agerastephen@yahoo.com; jamonng@yahoo.com
}

\begin{abstract}
This study investigated the effects of potting media on seed germination and early seedling growth of Pterocarpus erinaceus Poir at the Forestry Nursery in Jos, Nigeria. Using Completely Randomized Design (CRD) with three replicates, laboratory-tested soil samples, top soil, sharp sand, sharp sand + top soil, sharp sand + top soil + cow dung and sharp sand + top soil + poultry droppings were used in various combinations to assess the growth parameters of $P$. erinaceus (germination percentage, emergence, plant height, number of leaves, length of leaves and stem diameter) for 12 weeks. Descriptive and inferential statistics were employed to analyze collected data. Result indicated that sharp sand + top soil + poultry droppings had the highest nitrogen concentration (2.19\%), sharp sand + top soil + cow dung (2.07\%), sharp sand + top soil $(1.50 \%)$, top soil $(0.72 \%)$ and Sharp sand $(0.38 \%)$. Potting media with poultry droppings recorded an overall higher percentage germination of $42.9 \%$ by the end of the germination period. Analysis of variance (ANOVA) of collected data on combined soil aggregate on growth parameters indicated a significant $(\mathrm{p} \leq 0.05)$ difference in plant height, number of leaves, leaf length and stem diameter. Potting with poultry dropping gave the best potting media growth results when compared to other treatments that enhanced seed germination and seedling growth of $P$. erinaceus. This superior observation of the poultry droppings incorporated potting mixtures over the cow dung provides an outstanding potentials to enhance $P$. erinaceus plantation establishment. Consequently, recommended for raising seedlings in the nursery as well as ensuring sustainable management.
\end{abstract}

\section{DOI: https://dx.doi.org/10.4314/jasem.v25i6.11}

Copyright: Copyright (C) 2021 Peter et al. This is an open access article distributed under the Creative Commons Attribution License (CCL), which permits unrestricted use, distribution, and reproduction in any medium, provided the original work is properly cited.

Dates: Received: 20 March 2021; Revised: 27 April 2021; Accepted: 07 May 2021

Keywords: Pterocarpus erinaceus, Germination, Seedling Growth and Potting Media

Pterocarpus erinaceus Poir is of great interest for agroforestry systems, as it helps to improve soil fertility. Increased demand for rosewood as a timber species is competing greatly with its importance as a source of fodder, uses that are crucial to the livelihoods of the farmers and cattle rearing in regions where they are located (Abdul-Rahman et al., 2008). P. erinaceus trees are frequently harvested from natural and protected areas (Olafadehan, 2013) and the leaves are sold in urban centers as livestock fodder due to its high palatability potential (Orwa et al., 2009; AbdulRahman et al., 2008), therefore seedlings at the nursery or those planted out in the field may suffer heavy defoliation where protective measures fail. Despite the over use of $P$. erinaceus, producing countries have scanty scientific and technical information to guide forestry establishment and integration of the species into reforestation programs. However, few studies on the current status of $P$. erinaceus populations are available and generally concern the description of $P$. erinaceus habitats in the Sudanian zone (dry forests and woodlands) (Glèlè $e t$ al., 2008; Ouedraogo et al., 2006; Cuny et al., 1997). One of the problems with this species according to Karsten et al., (2014), is the difficulty of raising seedlings from seeds due to its hard impermeable seed coats restricting the entry of both water and oxygen that will aid its germination. Based on this, the use of suitable growing media is very important for production of quality plant seedlings which directly affects the growth, development and maintenance of the functional rooting system. A good growing medium would also provide sufficient support to plant; serve as reservoir for nutrients and water, allow oxygen diffusion to the roots and permit gaseous exchange between the roots and atmosphere outside the root substrate (Abad et al., 2002). Nursery potting media therefore influence quality of seedlings produced (Agbo and Omaliko, 2006). The quality of seedling obtained from a nursery influences reestablishment in the field and the eventual productivity of an orchard (Baiyeri, 2006). Thus, the aim for this study was to evaluate various potting media in order to ascertain the most suitable medium for the 
germination and early seedling growth of $P$. erinaceus to enhance its success in propagation and cultivation in the study area.

\section{MATERIALS AND METHODS}

Study Area: The study was conducted within the nursery of the Department of Forestry Technology, Federal College of Forestry Jos, Plateau State. The study area lies in the Northern Guinea Savannah situated along latitude $9^{0} 57^{1} \mathrm{~N}$ and longitude $8^{0} 54^{1} \mathrm{E}$ with an elevation of about $118 \mathrm{~m}$ above sea level. The mean annual rainfall for the location is between $1200 \mathrm{~mm}$ and $1250 \mathrm{~mm}$ and mean temperature ranges between $23^{\circ} \mathrm{C}$ and $25^{\circ} \mathrm{C}$. The soil is sandy-loam, light to dark in colour. The climate of the state is cool due to its high altitude and rainy season is usually between April and September while the dry season is from October to March (UJMS, 2000; Alao and Adeoye, 2004).

Soil Sample Collection and Analysis: All soil samples collected for routine analysis were carefully labeled for identification and taken to the soil/chemistry laboratory of the Federal College of Forestry, Jos where the samples were air dried at room temperature. The air-dried samples were then crushed using a mortar, pestle and then sieved using a $2.00 \mathrm{~mm}$ diameter sieve. The sieved samples were taken to the Agricultural Service Training Center (ASTC), Kassa, Vom, Plateau state, Nigeria for routine analysis. The chemical composition of the soil sources, viz: $\mathrm{pH}, \mathrm{N}$, organic matter, $\mathrm{P}, \mathrm{Na}, \mathrm{Ca}, \mathrm{Mg}$ and $\mathrm{K}$ concentrations were assessed using standard procedures as outlined by Soil and Plant Analysis Council (1999).

Research Design: A total number of 15 perforated polythene bags $(20 \times 5 \mathrm{~cm})$ containing $3 \mathrm{~kg}$ of soil were laid out in a completely randomized design (CRD) with 5 treatments (top soil, sharp sand, sharp sand and top soil, mixture of sharp sand, top soil and cow dung at a ratio of 1:2:1 and mixtures of sharp sand, top soil and poultry droppings at a ratio of 1:2:1). Poultry droppings and cow dung were each applied at the rate of $2 \mathrm{~kg}$ per $3 \mathrm{~kg}$ of soil before sowing (Ufere et al., 2013). The treatments were replicated three times.

Seed Planting, Assessment of Germination and Growth: Two seeds of Pterocarpus erinaceus obtained from the mother tree were planted on each of the potting media at a depth of $2 \mathrm{~cm}$. From each polythene pot, one seedling was later thinned to one stand per pot four weeks after germination (Kyei, 2016; Ufere et al., 2013). Data on seedling emergence was taken to assess the germination percentage. Plant height $(\mathrm{cm})$ was taken weekly from the soil level (base) to the tip using a graduated meter rule. The leaves of every seedling in the replicates were counted and the mean per replicate was determined. Leaf length was measured with a meter rule while stem diameter was measured using a thread, clung around the stem of each seedling and read against a graduated meter rule (in centimeters).

Statistical Analysis: The data obtained was subjected to descriptive (percentages and relative frequencies) and inferential statistical analysis of variance to determine their significance at 5\% level using Statistical Package for Social Sciences (SPSSC) version 23. Means separated using Duncan Multiple Range Test $(\mathrm{P} \leq 0.05)$.

\section{RESULTS AND DISCUSSION}

Physico-chemical Parameters of Soil: The soil $\mathrm{pH}$ in both distilled water and $\mathrm{CaCl}_{2}$ were slightly alkaline in nature for sharp sand $(8.90 ; 8.30)$ and combination of sharp sand and top soil $(8.60 ; 8.08$ respectively) while top soil alone had $\mathrm{pH}$ values in water and $\mathrm{CaCl}_{2}$ of (5.30 and 5.00 respectively). The combination of sharp sand, top soil and cow dung $(5.95 ; 5.35)$ and combination of sharp sand, top soil and poultry droppings $(6.60 ; 6.08)$ were slightly acidic respectively (Table 1). Percentage nitrogen was higher in soil combination of sharp sand, top soil and poultry droppings $(2.19 \%)$; than in soil mixture of sharp sand, top soil and cow dung (2.07\%), sharp sand and top soil $(1.50 \%)$, top soil $(0.72 \%)$ and sharp sand alone $(0.38 \%)$ and therefore shows that percentage nitrogen helped in improving soil fertility and plant growth. These findings are in consonance with Wiater and Chwil, (2005) who noted that nitrogen has profound effect on soil fertility, crop yields and the nutrient contributes to an increase in yield and after-harvest residue, thus preventing loss of soil organic matter. Organic matter content was highest in soil combination of sharp sand, top soil and poultry droppings $(8.67 \%)$ than in soil combination of sharp sand, top soil and cow dung (5.60\%); top soil alone (2.86\%); sharp sand and top soil (2.31\%) and sharp sand alone $(1.86 \%)$. Phosphorus concentration was highest in the soil combination of sharp sand, top soil and poultry droppings (13.6ppm) than in other soil combinations. The result on CEC and exchangeable bases [sodium $(\mathrm{Na})$, calcium $(\mathrm{Ca})$, Magnesium $(\mathrm{Mg})$ and Potassium (K)] was also highest in soil combination of sharp sand, top soil and poultry droppings. Effect of Potting Media on Seed Percentage Germination of Pterocarpus erinaceus Poir: There was significant variation $(\mathrm{p} \leq 0.05)$ among potting media in seed germination percentage. The mean germination percentage varied from $19.0 \%$ to $42.9 \%$ (Figure 1). Mixture of sharp sand, top soil and poultry dropping $(\mathrm{SS}+\mathrm{TS}+\mathrm{PD})$ recorded highest germination percentage $(42.9 \%)$. 


\begin{tabular}{|c|c|c|c|c|c|c|c|c|c|c|c|c|c|c|c|}
\hline \multirow[t]{2}{*}{ SAMPLE } & \multicolumn{2}{|c|}{ pH } & \multirow[t]{2}{*}{$\mathbf{N \%}$} & \multirow{2}{*}{$\begin{array}{l}\text { OM } \\
\%\end{array}$} & \multirow{2}{*}{$\begin{array}{l}\text { Available } \\
\text { P ppm \% }\end{array}$} & \multicolumn{4}{|c|}{ Exchangeable Bases (ppm) } & \multirow{2}{*}{$\begin{array}{l}\text { Exchangea } \\
\text { ble Acidity } \\
\text { mMol/100g } \\
\mathbf{A l}^{3+}\end{array}$} & \multirow{2}{*}{$\begin{array}{l}\text { CEC } \\
\text { mMol } \\
/ 100 \mathrm{~g}\end{array}$} & \multirow{2}{*}{$\begin{array}{l}\text { Clay } \\
\%\end{array}$} & \multirow{2}{*}{$\begin{array}{l}\text { Silt } \\
\%\end{array}$} & \multirow{2}{*}{$\begin{array}{l}\text { Sand } \\
\%\end{array}$} & \multirow{2}{*}{$\begin{array}{l}\text { Textural } \\
\text { Class }\end{array}$} \\
\hline & $\mathrm{H}_{2} \mathrm{O}$ & $\mathrm{CaCl}_{2}$ & & & & $\begin{array}{l}\mathrm{Na} \\
\%\end{array}$ & $\begin{array}{l}\mathbf{C a} \\
\%\end{array}$ & $\begin{array}{l}\mathbf{M g} \\
\%\end{array}$ & $\begin{array}{l}\mathbf{K} \\
\%\end{array}$ & & & & & & \\
\hline TS & 5.30 & 5.00 & 0.72 & 2.86 & 1.35 & 1.03 & 405 & 69 & 151 & Nil & 6.62 & 17.8 & 24.4 & 57.8 & $\begin{array}{ll}\text { Sandy } & \text { Clay } \\
\text { Loam }\end{array}$ \\
\hline SS & 8.90 & 8.30 & 0.38 & 1.86 & 0.98 & 0.67 & 278 & 43 & 100 & Nil & 4.87 & 5.5 & 7.4 & 87.1 & Sandy \\
\hline $\mathrm{SS}+\mathrm{TS}$ & 8.60 & 8.08 & 1.50 & 2.31 & 1.08 & 1.00 & 304 & 58 & 110 & Nil & 5.4 & 16.3 & 18.2 & 65.5 & Loamy Sand \\
\hline $\mathrm{SS}+\mathrm{TS}+\mathrm{CD}$ & 5.95 & 5.35 & 2.07 & 5.60 & 6.30 & 1.19 & 624 & 123 & 189 & Nil & 8.05 & 14.24 & 18.0 & 67.76 & Loamy Sand \\
\hline $\mathrm{SS}+\mathrm{TS}+\mathrm{PD}$ & 6.60 & 6.08 & 2.19 & 8.67 & 13.6 & 1.34 & 1060 & 265 & 230 & Nil & 13.7 & 15.01 & 17.47 & 68.02 & Sandy Loam \\
\hline
\end{tabular}

WHERE $:$ TS = Top Soil; SS = Sharp Sand; SS + TS = Sharp Sand + Top Soil; SS + TS + CD = Sharp Sand + Top Soil + Cow Dung; SS + TS + PD = Sharp Sand + Top Soil + Poultry Droppings

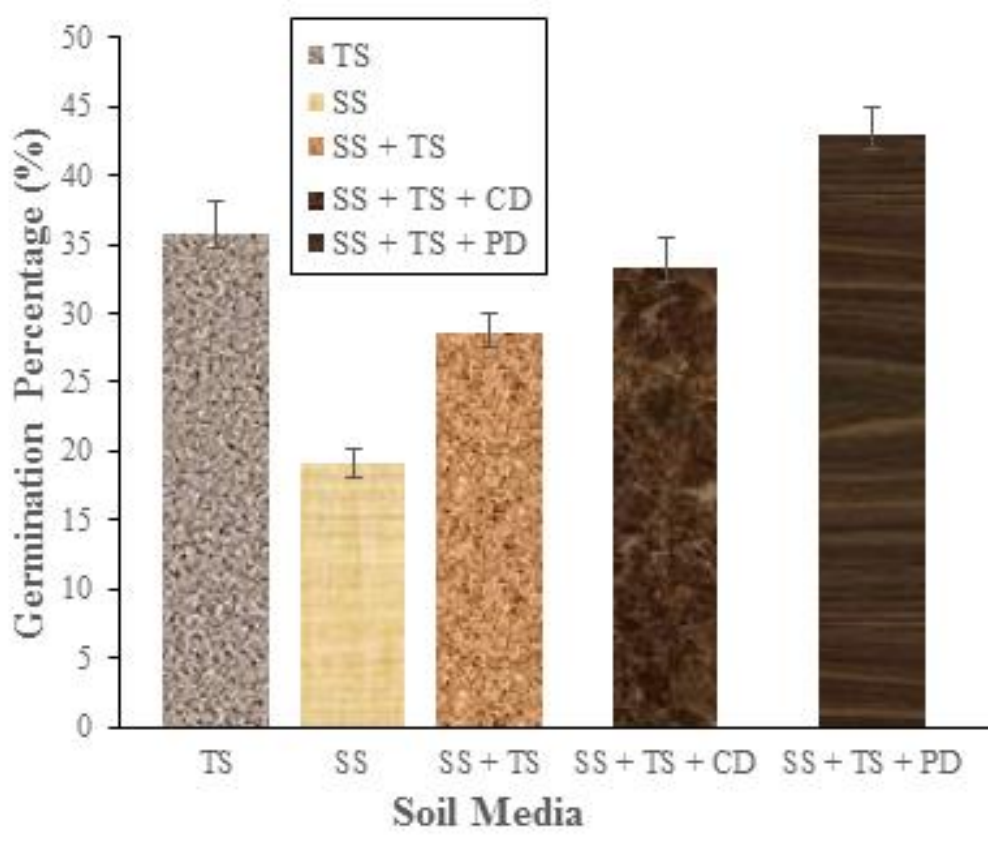

Fig 1: Effect of Potting Media on Percentage Germination of P. erinaceus Poir

KEY: TS = Top Soil $;$ SS = Sharp Sand $;$ SS + TS = Sharp Sand + Top Soil $;$ SS + TS + CD = Sharp Sand + Top Soil + Cow Dung; SS + TS + PD = Sharp Sand + Top Soil + Poultry Droppings 
This was followed by top soil (35.7\%), combination of sharp sand, top soil and cow dung (SS + TS + CD) had a germination percentage of $33.3 \%$, sharp sand and top soil (SS + TS) $(28.6 \%)$ while seeds planted in sharp sand (SS) exhibited the lowest germination percentage $(19.0 \%)$ and the order of performance were SS + TS + $\mathrm{PD}>\mathrm{TS}>\mathrm{SS}+\mathrm{TS}+\mathrm{CD}>\mathrm{SS}+\mathrm{TS}>\mathrm{SS}$. The results agree with the findings of Okunomo, (2010) who observed that the significant higher germination percentage of Parkia bicolor (A. cheu) seedlings sown in poultry dropping potting media could be attributed to the availability of nitrogen, phosphorus and potassium which aided in boosting seed germination when compared with other source of manures. Effect of Potting Media on Seedling Growth of Pterocarpus erinaceus Poir: The effect of potting media on mean seedling height $(\mathrm{cm})$ of Pterocarpus erinaceus Poir were significantly $(\mathrm{p} \leq 0.05)$ different at $5^{\text {th }}$ to $12^{\text {th }}$ weeks after germination (Table 2). Results of the study equally showed increase in seedling height as the weeks increased and the highest value for each stage was obtained from poly pots with combined potting media of sharp sand, top soil and poultry droppings $(\mathrm{SS}+\mathrm{TS}+\mathrm{PD})$, this was followed in order of performance as sharp sand, top soil and cow dung (SS $+\mathrm{TS}+\mathrm{CD})>$ Top soil $(\mathrm{TS})>$ sharp sand and top soil $(\mathrm{SS}+\mathrm{TS})>$ sharp sand $(\mathrm{SS})$. The highest height $(\mathrm{cm})$ of Pterocarpus erinaceus seedlings recorded under poly pot with combination of poultry droppings revealed better performance of the seedlings. This supports the report of Imoro et al., (2012) who reported that height of seedlings treated with decomposed poultry manure produced the highest height compared to those treated with decomposed cow dung manure and controls respectively. This was also in conformity with the findings of Ghanbarian et al. (2008) as well as Bahl and Toor (2002) who reported that soil mixture with poultry droppings contained high concentrations of nitrogen and phosphorus, which aid in boosting plant height. The effect of potting media on mean leaf number of Pterocarpus erinaceus Poir were significantly $(\mathrm{p} \leq 0.05)$ different at $5^{\text {th }}$ to $12^{\text {th }}$ weeks after germination (Table 3). The result indicate the incremental number of leaves of $P$. erinaceus seedlings post-germination. The highest value for each stage was obtained from poly pots with combined potting media of SS + TS + $\mathrm{PD}$, this was followed in order of performance as $\mathrm{SS}+$ $\mathrm{TS}+\mathrm{CD}>\mathrm{TS}>\mathrm{SS}+\mathrm{TS}>\mathrm{SS}$ respectively. This was in agreement with findings by Agera et al. (2019) who reported highest performance from poultry droppings on leaf number of Eucalyptus camaldulensis seedlings. The reasons for higher performance on number of leaves are attributable to higher nitrogen concentrations (Edmeades and Lafitte, 1993; Tindall, 1992). This therefore disagrees with the work of Imobighe (2004) and Okunomo et al., (2006) who obtained highest performance on number of leaves of tree seedlings with the use of cow dung. The result also agrees with the work of Okunomo (2010) who obtained highest number of leaves in poultry droppings with Parkia bicolor (A. Cheu).

Table 2: Effect of Potting Media on Mean Seedling Height $(\mathrm{cm})$ of Pterocarpus erinaceus Poir

\begin{tabular}{|c|c|c|c|c|c|c|c|c|}
\hline \multirow{2}{*}{$\begin{array}{l}\text { Potting } \\
\text { Media }\end{array}$} & \multicolumn{8}{|c|}{ Seedling Height (cm) } \\
\hline & 5WAG & 6WAG & 7WAG & 8WAG & 9WAG & 10WAG & 11WAG & 12WAG \\
\hline TS & $0.28^{\mathrm{a}}$ & $0.40^{\mathrm{ab}}$ & $1.10^{\mathrm{ab}}$ & $1.41^{\mathrm{ab}}$ & $1.61^{\mathrm{ab}}$ & $1.90^{\mathrm{ab}}$ & $2.51^{\mathrm{b}}$ & $3.25^{\mathrm{ab}}$ \\
\hline SS & $0.05^{\mathrm{b}}$ & $0.07^{\mathfrak{c}}$ & $0.26^{\mathbf{c}}$ & $0.36^{\mathbf{c}}$ & $0.43^{\mathrm{c}}$ & $0.59^{\mathbf{c}}$ & $0.87^{\mathfrak{c}}$ & $1.29^{\mathrm{c}}$ \\
\hline $\mathrm{SS}+\mathrm{TS}$ & $0.15^{\mathrm{b}}$ & $0.27^{\mathbf{b c}}$ & $0.71^{\mathbf{b c}}$ & $0.86^{\mathrm{bc}}$ & $1.08^{\mathbf{b c}}$ & $1.36^{\mathrm{bc}}$ & $1.99^{\mathrm{b}}$ & $2.59^{\mathbf{b c}}$ \\
\hline $\mathrm{SS}+\mathrm{TS}+\mathrm{CD}$ & $0.30^{\mathrm{a}}$ & $0.58^{\mathrm{a}}$ & $1.18^{\mathrm{ab}}$ & $1.48^{\mathrm{ab}}$ & $1.76^{\mathrm{ab}}$ & $2.03^{\mathrm{ab}}$ & $2.99^{\mathrm{ab}}$ & $3.77^{\mathrm{ab}}$ \\
\hline $\mathrm{SS}+\mathrm{TS}+\mathrm{PD}$ & $0.36^{\mathrm{a}}$ & $0.51^{\mathrm{ab}}$ & $1.29^{\mathrm{a}}$ & $1.60^{\mathrm{a}}$ & $2.11^{\mathrm{a}}$ & $2.63^{\mathrm{a}}$ & $3.75^{\mathrm{a}}$ & $4.66^{\mathrm{a}}$ \\
\hline SE & 0.05 & 0.08 & 0.18 & 0.23 & 0.25 & 0.29 & 0.39 & 0.50 \\
\hline$p$-value & 0.000 & 0.000 & 0.001 & 0.001 & 0.000 & 0.000 & 0.000 & 0.000 \\
\hline
\end{tabular}

Values (in the same column) with the same subscript letters do not differ significantly from each other according to the Duncan multiple range test.

KEY $: T S=$ Top Soil $;$ SS = Sharp Sand $;$ SS + TS = Sharp Sand + Top Soil; SS + TS + CD = Sharp Sand + Top Soil + Cow Dung; SS + TS $+P D=$ Sharp Sand + Top Soil + Poultry Droppings

Table 3: Effect of Potting media on Mean Number of Leaves of Pterocarpus erinaceus Poir Seedlings

\begin{tabular}{|c|c|c|c|c|c|c|c|c|}
\hline \multirow{2}{*}{$\begin{array}{l}\text { Potting } \\
\text { Media }\end{array}$} & \multicolumn{8}{|c|}{ Number Of Leaves } \\
\hline & 5WAG & 6WAG & 7WAG & 8WAG & 9WAG & 10WAG & 11WAG & 12WAG \\
\hline TS & $0.86^{\mathrm{a}}$ & $1.62^{\mathrm{ab}}$ & $3.67^{\mathrm{a}}$ & $5.62^{\mathrm{a}}$ & $5.81^{\mathrm{a}}$ & $7.00^{\mathbf{a b}}$ & $8.43^{\mathrm{a}}$ & $8.67^{\mathrm{ab}}$ \\
\hline SS & $0.24^{\mathrm{b}}$ & $0.38^{\mathrm{c}}$ & $1.10^{\mathrm{b}}$ & $1.91^{\mathrm{b}}$ & $2.14^{\mathrm{b}}$ & $2.57^{\mathrm{c}}$ & $3.19^{\mathrm{b}}$ & $3.57^{\mathrm{c}}$ \\
\hline $\mathrm{SS}+\mathrm{TS}$ & $0.43^{\mathbf{b}}$ & $1.05^{\mathrm{bc}}$ & $2.48^{\mathrm{ab}}$ & $3.52^{\mathrm{ab}}$ & $3.81^{\mathrm{ab}}$ & $5.43^{\mathrm{bc}}$ & $6.62^{\mathrm{ab}}$ & $6.91^{\mathrm{bc}}$ \\
\hline $\mathrm{SS}+\mathrm{TS}+\mathrm{CD}$ & $0.91^{\mathrm{a}}$ & $2.33^{\mathrm{a}}$ & $3.57^{\mathrm{a}}$ & $5.38^{\mathrm{a}}$ & $5.62^{\mathrm{a}}$ & $7.10^{\mathbf{a b}}$ & $8.81^{\mathrm{a}}$ & $8.91^{\text {ab }}$ \\
\hline $\mathrm{SS}+\mathrm{TS}+\mathrm{PD}$ & $0.91^{\mathrm{a}}$ & $2.29^{\mathrm{a}}$ & $4.00^{\mathrm{a}}$ & $6.19^{\mathrm{a}}$ & $6.57^{\mathrm{a}}$ & $8.95^{\mathrm{a}}$ & $10.62^{\mathrm{a}}$ & $11.00^{\mathrm{a}}$ \\
\hline SE & 0.14 & 0.32 & 0.57 & 0.92 & 0.92 & 1.11 & 1.34 & 1.33 \\
\hline$p$-value & 0.002 & 0.000 & 0.004 & 0.008 & 0.008 & 0.002 & 0.003 & 0.003 \\
\hline
\end{tabular}

Values (in the same column) with the same subscript letters do not differ significantly from each other according to the Duncan multiple range test.

KEY $:$ TS = Top Soil $;$ SS = Sharp Sand $; S S+T S=$ Sharp Sand + Top Soil; SS + TS + CD = Sharp Sand + Top Soil + Cow Dung; SS + TS $+P D=$ Sharp Sand + Top Soil + Poultry Droppings 
There was a significant increase in length of leaves as the seedling age increased based on the effects of different potting media from week 5 through to week 12 weeks after germination (Table 4). However, results of the study equally shows increase in length of leaves as the weeks increases and the highest value for each stage was obtained from poly pots with combined potting media of SS + TS + PD, this was followed in order of performance as $\mathrm{TS}>\mathrm{SS}+\mathrm{TS}+\mathrm{CD}>\mathrm{SS}+$ TS > SS. This may be attributed to absorption of nutrient in the soil mixture with the presence of poultry droppings which favoured faster vegetative growth. This corroborates the findings of Agera et al. (2019) who stated that poultry manure was richer in their nitrogen and other nutrient content, thus aid in faster vegetative growth. This is also in consonance with reports recorded by other investigators such as Abou El-Magd, et al. (2006), who stated that the greatest leaf length after trails between October 2007 and December 2007 was recorded from poultry manure. The result further agrees with Imoro et al. (2012), who indicated that poultry manure is a valuable source of fertilizer for the growth of tree seedlings because it had greatly improved growth performance of vegetative parts of treated plants. Mixing of river sand with nutrient-rich top soil and nutrient-rich poultry droppings had a synergistic effect in supporting and improving soil conditions for seedling growth. Manuring can improve soil physical, chemical and biological properties leading to beneficial effects on $T$. africana seedling production (Agera, et al. 2019).

Table 4: Effect of Potting media on Mean Length of Leaves of Pterocarpus erinaceus Poir Seedlings

\begin{tabular}{|c|c|c|c|c|c|c|c|c|}
\hline \multirow{2}{*}{$\begin{array}{l}\text { Potting } \\
\text { Media }\end{array}$} & \multicolumn{8}{|c|}{ Length Of Leaves (cm) } \\
\hline & 5WAG & 6WAG & 7WAG & 8WAG & 9WAG & 10WAG & 11WAG & 12WAG \\
\hline TS & $0.11^{\mathrm{a}}$ & $0.55^{\mathrm{ab}}$ & $1.51^{\mathrm{ab}}$ & $1.89^{\mathrm{ab}}$ & $1.99^{\mathrm{ab}}$ & $2.01^{\mathrm{ab}}$ & $2.37^{\mathrm{ab}}$ & $2.37^{\mathrm{ab}}$ \\
\hline SS & $0.02^{\mathrm{b}}$ & $0.13^{\mathrm{c}}$ & $0.51^{\mathrm{c}}$ & $0.66^{\mathrm{c}}$ & $0.77^{\mathrm{c}}$ & $0.77^{\mathrm{c}}$ & $0.97^{\mathrm{c}}$ & $0.99^{c}$ \\
\hline $\mathrm{SS}+\mathrm{TS}$ & $0.05^{\mathbf{b}}$ & $0.39^{\mathbf{b c}}$ & $1.08^{\mathbf{b c}}$ & $1.34^{\mathrm{bc}}$ & $1.38^{\mathrm{bc}}$ & $1.39^{\mathrm{bc}}$ & $1.64^{\mathrm{bc}}$ & $1.66^{\mathrm{bc}}$ \\
\hline $\mathrm{SS}+\mathrm{TS}+\mathrm{CD}$ & $0.13^{\mathrm{a}}$ & $0.68^{\mathrm{ab}}$ & $1.52^{\mathrm{ab}}$ & $1.87^{\mathrm{ab}}$ & $2.02^{\mathbf{a b}}$ & $2.02^{\mathrm{ab}}$ & $2.30^{\mathbf{a b}}$ & $2.30^{\mathbf{a b}}$ \\
\hline $\mathrm{SS}+\mathrm{TS}+\mathrm{PD}$ & $0.11^{\mathrm{a}}$ & $0.73^{\mathrm{a}}$ & $2.22^{\mathrm{a}}$ & $2.64^{\mathrm{a}}$ & $2.77^{\mathrm{a}}$ & $2.83^{\mathrm{a}}$ & $3.11^{\mathrm{a}}$ & $3.13^{\mathrm{a}}$ \\
\hline SE & 0.02 & 0.11 & 0.28 & 0.34 & 0.35 & 0.35 & 0.39 & 0.38 \\
\hline$p$-value & 0.001 & 0.001 & 0.001 & 0.003 & 0.003 & 0.002 & 0.003 & 0.003 \\
\hline
\end{tabular}

Values (in the same column) with the same subscript letters do not differ significantly from each other according to the Duncan multiple
range test.

KEY: TS = Top Soil; $S S=$ Sharp Sand; SS + TS = Sharp Sand + Top Soil; $S S+T S+C D=$ Sharp Sand + Top Soil + Cow Dung; SS + TS $+P D=$ Sharp Sand + Top Soil + Poultry Droppings

Table 5: Effect of Potting media on Mean Stem Diameter (cm) of Pterocarpus erinaceus Poir Seedlings

\begin{tabular}{|c|c|c|c|c|c|c|c|c|}
\hline \multirow{2}{*}{$\begin{array}{l}\text { Potting } \\
\text { Media }\end{array}$} & \multicolumn{8}{|c|}{ Stem Diameter $(\mathbf{c m})$} \\
\hline & 5WAG & 6WAG & 7WAG & 8WAG & 9WAG & 10WAG & 11WAG & 12WAG \\
\hline TS & $0.14^{\mathrm{a}}$ & $0.15^{\mathrm{ab}}$ & $0.33^{\mathrm{ab}}$ & $0.35^{\mathrm{ab}}$ & $0.35^{\mathrm{ab}}$ & $0.39^{\mathrm{ab}}$ & $1.15^{\mathrm{a}}$ & $1.17^{\mathrm{ab}}$ \\
\hline SS & $0.02^{\mathrm{b}}$ & $0.02^{\mathrm{c}}$ & $0.12^{\mathrm{c}}$ & $0.15^{\mathrm{b}}$ & $0.19^{\mathbf{b}}$ & $0.21^{\mathrm{b}}$ & $0.49^{\mathbf{b}}$ & $0.61^{\mathrm{b}}$ \\
\hline $\mathrm{SS}+\mathrm{TS}$ & $0.06^{\mathrm{b}}$ & $0.09^{\mathbf{b c}}$ & $0.22^{\mathbf{b c}}$ & $0.24^{\mathrm{b}}$ & $0.30^{\mathbf{b}}$ & $0.30^{\mathbf{b}}$ & $0.71^{\mathrm{ab}}$ & $0.84^{\mathrm{ab}}$ \\
\hline $\mathrm{SS}+\mathrm{TS}+\mathrm{CD}$ & $0.12^{\mathrm{a}}$ & $0.18^{\mathrm{a}}$ & $0.30^{\mathrm{abc}}$ & $0.30^{\mathbf{b}}$ & $0.32^{\mathrm{b}}$ & $0.37^{\mathrm{ab}}$ & $0.93^{\mathrm{ab}}$ & $1.02^{\mathrm{ab}}$ \\
\hline $\mathrm{SS}+\mathrm{TS}+\mathrm{PD}$ & $0.15^{\mathrm{a}}$ & $0.19^{b}$ & $0.46^{\mathrm{a}}$ & $0.51^{\mathrm{a}}$ & $0.53^{\mathrm{a}}$ & $0.51^{\mathrm{a}}$ & $1.25^{\mathrm{a}}$ & $1.37^{\mathrm{a}}$ \\
\hline SE & 0.02 & 0.03 & 0.06 & 0.07 & 0.07 & 0.07 & 0.18 & 0.18 \\
\hline p-value & 0.000 & 0.000 & 0.004 & 0.005 & 0.020 & 0.014 & 0.021 & 0.048 \\
\hline
\end{tabular}

Values (in the same column) with the same subscript letters do not differ significantly from each other according to the Duncan multiple range test.

KEY: TS = Top Soil; SS = Sharp Sand; SS + TS = Sharp Sand + Top Soil $;$ SS +; TS + CD = Sharp Sand + Top Soil + Cow Dung; SS + $T S+P D=$ Sharp Sand + Top Soil + Poultry Droppings

Result on table 5 displayed a significant difference $(p$ $\leq 0.05$ ) in seedling stem diameter from $5^{\text {th }}$ to $12^{\text {th }}$ week after germination. There was an increase in mean stem diameter as the seedling age increased based on the effects of different potting media throughout the trail periods $\left(5^{\text {th }}\right.$ to $12^{\text {th }}$ week post germination) and the highest value for each stage was obtained from poly pots with combined potting media of SS + TS + PD, this was followed in order of performance as SS + TS $+\mathrm{CD}>\mathrm{TS}>\mathrm{SS}+\mathrm{TS}>\mathrm{SS}$. This is in line with Imoro, et al., (2012) who stated that poultry manure produces better growth attributes such as stem girth than its counterparts produced and this may probably be due to the fact that poultry droppings contains more concentrated nutrients and hence led to enhanced plant growth performance in seedlings of plants treated with poultry droppings. This study also support works carried out by Okunomo and Bosah (2007); Imobighe (2004); and Okunomo et al., (2006) who reported the importance of poultry droppings for good growth, stem development and suitability of tree seedlings in terms of mineralization. The result also agrees with the work of Okunomo (2010) who obtained highest diameter in poultry droppings with Parkia bicolor (A. Cheu). The studies carried out by Jibo et al. (2018) on the effects of organic manure on growth performance of Azadirachta indica (A. JUSS) corroborate with the present findings showing that poultry manure improved the mean growth of stem diameter. 
Conclusion: The finding of this study showed that the germination percentage and early seedling growth of Pterocarpus erinaceus was best recorded in poultry droppings treated medium. This is consequent upon mineralization and nutrient uptake causing significant increase in growth of $P$. erinaceus, serving as good source of soil amendment which in turn resulted in improved germination. Thus, it is recommended that the use of organic manure (poultry droppings) in seedling production is desirable as it had variable impacts on seed germination and growth of $P$. erinaceus seedlings.

Acknowledgement: Special thanks to the Provost and all the staff and personnel at the college Nursery of the Federal College of Forestry, Jos-Nigeria, Laboratory Staff and the Co-Authors for all their efforts in achieving the recorded success.

\section{REFERENCES}

Abad M; Noguera P; Puchades R; Maquieira A; Noguera, V (2002). Physico-chemical and chemical properties of some coconut dusts for use as a peat substitutes for containerized ornamental plants. Biores. Technol. 82: 241-245

Abdul-Rahman, AA; Ihaza, OC; Oladele, FA (2008). Survey of some economic trees and their exploitation in Irepodun Local Government area of Kwara State, Nigeria. BEST Journal 6(1), 57-60.

Abou El- Magd, MM; Hoda AM; Fawzy, ZF (2006). Effect of organic manure with or without chemical fertilizers on growth, yield and quality of some varieties of broccoli plants. J. Appl. Sci. Res., 2(10): 791-798.

Agbo, CU; Omaliko, CM (2006). Initiation and growth of shoots of Gongronema latifolia Benth stem cuttings in different rooting media. Afr. J. Biotechn. 5: 425-428

Agera, SIN; Nzeli, NB; Ujah, AF (2019). Effect of potting media and organic manure dosage on the germination and early growth of Treculia africana (DECNE). J. Global Biosci.. 8(1): 5760-5773.

Agera, SIN; Peter, MK; Amonum, JI (2019). Assessment of seed germination and organic manure application on the early growth of Eucalyptus camaldulensis L. seedlings. Res. J. For., 13 (1): 1-8.

Alao DA; Adeoye, AE (2004). Environmental Impact assessment of mine tailing of abandon tin quarries at Barkin Ladi, Plateau State. Proceeding of the $5^{\text {th }}$ International Conference of the Nigeria Institution of Agricultural Engineers. 26: 154-159.

Bahl, GS; Toor, GS (2002). Influence of poultry manure on phosphorus availability and the standard phosphate requirement of crop estimated from quantity-intensity relationships in different soils. Bioresour. Technol., 85: 317-322.

Baiyeri, KP (2006). Seedling emergence and growth of pawpaw (Carica papaya) growth under different coloured shade polyethylene. Int. Agrophys. 20: In press.

Cuny, P; Sanogo, S; Sommer, N (1997). Arbres du domaine soudanien. Leurs usages et leur multiplication. IER, Sikasso, Mali \& Intercoopération, Bern, Switzerland (122 pp.)

Edmeades, GO; Lafitte, HR (1993). Defoliation and plant density on maize selected for reduced plant height. Agron. J., 85: 850 - 859.

Ghanbarian, D; Youneji, S; Fallah, S; Farhadi, A (2008). Effect of broiler litter on physical properties, growth and yield of two cultivars of cantaloupe (Cucumis melo L.). Int. J. Agric. Biol., 10: 697-700.

Glèlè, KRL; Sinsin, B; Palm, R (2008). Etude dendrométrique de Pterocarpus erinaceus Poir. des formations naturelles de la zone soudanienne au Bénin. Agronomie Africaine 20 (3), 245-255.

Imobighe, K (2004). Effect of organic manure on the growth and yield of Okra. MSc. Project (unpublished). Department of Vocational and technical education, Delta State University Abraka.

Imoro, AW; Sackey, MI; Abubakari, AH (2012). Preliminary Study on the Effects of Two Different Sources of Organic Manure on the Growth Performance of Moringa oleifera Seedlings; Journal of Biology, Agriculture and Healthcare. 1 2(10): 151-156.

Jibo, AU; Salami, KD; Inuha, IM (2018). Effects of Organic Manure on Growth Performance of Azadirachta indica (A. JUSS) Seedlings during Early Growth in the Nursery. FUDMA J. Sci. (FJS). 2(4): $99-105$.

Karsten, JR; Meilby, H; Larsen, BJ (2014). Regeneration and management of lesser-known timber species in the Peruvian Amazon following 
disturbance by logging. Forest Ecol. Manage. 327(1): 76-85.

Kyei, RK (2016). Effect of Different Pre-Sowing Treatments on the Germination and Initial Growth of Pterocarpus Erinaceus Seeds. 23-43.

Okunomo, K (2010). Germination and seedling growth of Parkia bicolor (A. Cheu) as influenced by various nursery techniques. Afr. J. Gen. Agric. 6 (4): $187-197$.

Okunomo, K; Bosah, BO (2007). Effect of organic manure on seedling growth and development of $A$. Senegal. Agric. J.. 2(6): 685-687.

Okunomo, K; Ureigho, UN; Opuste, HO (2006). The effect of soil amendment on the performance of Gambaya albida (Linn) seedlings. Eur. J. Sci. Res., 13: $244-250$.

Olafadehan, OA (2013). Feeding value of Pterocarpus erinaceus for growing goats. Animal Feed Science and Technology 185 (1-2), 1-8.

Orwa, C; Mutua, A; Kindt, R; Jamnadass, R; Anthony, $S$ (2009). Agroforestry tree Database: A tree reference and selection guide version 4.0. World Agroforestry Centre, Kenya. http://www.worldagroforestry.org/sites/treedbs/tre edatabases.asp Accessed 14 March 2021.
Ouedraogo, A; Adjima, T; Hahn-Hadjali, K; Guinko, S (2006). Diagnostic de l'état de dégradation des peuplements de quatre espèces ligneuses en zone soudanienne du Burkina Faso. Sécheresse 17 (4), 485-491.

Soil and Plant Analysis Council Inc., (1999). Soil Analysis: Handbook of Reference Methods. CRC Press, Boca Raton, FL., USA. ISBN-13: 9780849302053, Pages: 264.

Tindall, HD (1992). Vegetables in the tropics. Macmillan Press Ltd, London, 533.

Ufere N; Uka, K; Chukwuka, S; Mary, I (2013). Relative effect of organic and inorganic fertilizer on the growth of Okra (Abelmoschus esculentus (L) Moench) J. Agric. Sci. 58 (3): 159-166.

University of Jos Meteorological Station (UJMS) (2000). Annual report on the assessment of temperature, relative humidity and rainfall variations within the middle belt region, 1-189.

Wiater, J; Chwil, S (2005).The influence of mineral fertilization on the content of mineral nitrogen forms in the medium soil. Frag. Agron, XXII: 613623. 